
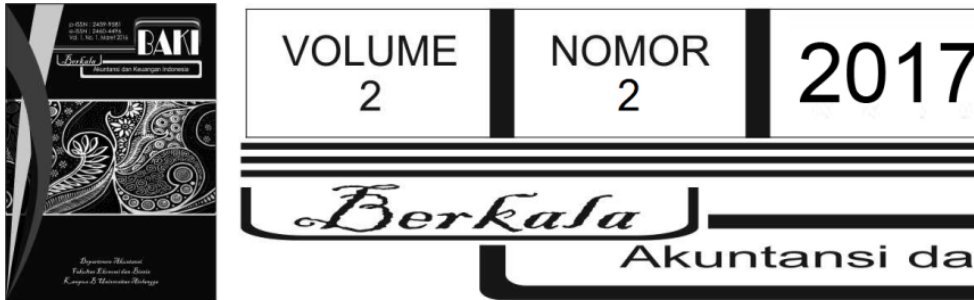

L3erkata

Akuntansi dan Keuangan Indonesia

\title{
Pengaruh Kompetensi dan Sistem Pengendalian Internal Terhadap Akuntabilitas Pemerintah Desa dalam Mengelola Alokasi Dana Desa (ADD)
}

\author{
Arif Widyatama ${ }^{1}$ \\ Lola Novita ${ }^{1}$ \\ Diarespati ${ }^{1,2}$ \\ 1STIE Panca Bhakti Palu \\ 2 diarespati1987@gmail.com
}

\section{N F O ARTIKEL}

Histori Artikel:

Tanggal Masuk 3 Juli 2017

Tanggal Diterima 2 Agustus 2017

Tersedia Online 30 September 2017

Kata Kunci:

akuntabilitas; alokasi dana desa; kompetensi aparatur; sistem pengendalian internal

\begin{abstract}
ABSTRAK
Tujuan dari penelitian ini untuk mengetahui dan menganalisis pengaruh Kompetensi dan Sistem Pengendalian Internal terhadap Akuntabilitas Pemerintah Desa dalam mengelola Alokasi Dana Desa, Sejauh mana Penerapan Faktor Kompetensi dan Sistem Pengendalian Internal dengan menggunakan Accountability Framework dan untuk mengetahui kendala - kendala yang dihadapi aparatur pemerintah dalam meningkatkan Akuntabilitas Pengelolaan Alokasi Dana Desa (ADD).Penelitian ini menggunakan explanatory research, tempat penelitian di Kabupaten Sigi dengan jumlah sampel sebanyak 61 sampel dengan menggunakan random sampling. Teknik analisis yang digunakan Regresi Linear Berganda, uji hipotesis menggunakan taraf signifikansi $\alpha=0,05$ dengan bantuan program SPSS versi 16,00. Uji validitas dengan teknik corrected item-total correlation dengan syarat minimum $r=0,3$. Uji reliabilitas dengan menggunakan koefisien Cronbach Alpha dengan batas koefisien a $>0,6$. Hasil analisis pengujian hipotesis menunjukkan variabel Kompetensi Aparatur tidak berpengaruh signifikan terhadap Akuntabilitas dalam Pengelolaan ADD, sedangkan variabel Sistem Pengendalian Internal memberikan pengaruh positif terhadap Akuntabilitas dalam Pengelolaan ADD.
\end{abstract}

\section{Pendahuluan}

Akuntabilitas merupakan hal yang penting untuk dimiliki oleh entitas baik entitas bisnis maupun pemerintah sebagai bentuk pertanggungjawaban kepada shareholders. Pemerintah merupakan sebuah organisasi yang bertugas untuk melayani masyarakat. Di sektor privat, 
akuntabilitas akan muncul secara otomatis apabila entitas telah atau dalam proses melakukan penerbitan efek di pasar modal dan entitas menguasai aset dalam kapasitas sebagai fidusia untuk sekelompok besar masyarakat (Narsa dan Isnalita 2017). Berbeda dengan sektor privat, akuntabilitas di sektor publik merupakan suatu hal yang sudah pasti akan muncul. Akuntabilitas bagi pemerintah dinilai sangat penting untuk dimiliki disebabkan adanya akuntabilitas tersebut akan dapat meningkatkan kepercayaan masyarakat terhadap aktivitas yang telah dilakukan oleh pemerintah. Scott (2006) mengatakan bahwa sebagai pengelola sumber daya, maka masyarakat membutuhkan informasi yang terkait dengan aktivitas yang dilakukan oleh pengelola tersebut yakni pemerintah. Informasi ini sangat dibutuhkan oleh masyarakat guna mengetahui seberapa besar sumber daya yang dimiliki serta mengalokasikan sumber daya tersebut. Pendapat ini dipertegas oleh (Jorge et al. 2011) yang mengemukakan bahwa masyarakat perlu mengetahui sumber daya yang dimiliki oleh daerah dan mengalokasikan sumber daya tersebut. Sehingga jika pemerintah mengedepankan akuntabilitas dan transparansi maka masyarakat dapat mendukung segala aktivitas yang dilakukan oleh pemerintah.

Akuntabilitas menjadi sebuah kontrol penuh aparatur atas segala sesuatu yang telah dilakukan dalam sebuah pemerintahan, sehingga peran pemerintah selaku agen menjadi sebuah faktor penting dalam mempertanggungjawabkan kinerja dari pemerintahan kepada prinsipal atau rakyat.Untuk mendukung keberhasilan akuntabilitas dan transparansi dalam sebuah pemerintahan maka banyak faktor yang dapat memengaruhi kedua aspek tersebut. (Cheng et al., 2002) menyebutkan bahwa kompetensi yang dimiliki oleh aparatur pemerintahan turut memengaruhi akuntabilitas dan transparansi pemerintah desa.Lebih lanjut, Kalbers dan Forgaty (1995) menambahkan selain adanya internal controlling dalam sebuah pemerintahan turut memengaruhi tingkat akuntabilitas dan transpararnsi public. (Kurtz dan Schrank 2007) juga memberikan argumennya yang menyebutkan bahwa faktor yang menentukan akuntabilitas dan transparansi suatu pemerintahan adalah implementasi Good Government Governance.Faktor yang tidak kalah pentingnya adalah sistem pengendalian dalam pemerintahan, disebabkan adanya sistem pengendalian dapat memengaruhi pengambilan keputusan internal pemerintah Desa dan dapat berimplikasi pada akuntabilitas dan transparansi pemerintah Desa tersebut. Ditambahkan oleh Uddin dan Hopper (2001) bahwa pimpinan dalam sebuah organisasi memiliki bentuk pengendalian agar dalam sistem perencanaan (penganggaran desa) output yang dihasilkan memiliki kontribusi yang bermanfaat bagi masyarakat Desa. Pengamatan peneliti di lapangan khususnya di pemerintah Desatingkat akuntabilitas dan transparansi masih sangat rendah. Hal ini didukung dengan temuan yang dipaparkan oleh Indonesia Aksi-Corupption Forum (IACF 2010) yang menyebutkan potensipotensi penyalahgunaan dana Desa disebabkan oleh minimnya pengetahuan yang dimiliki oleh aparatur pemerintah Desadan sistem pengendalian intern. Di sisi lain berdasarkan PP Nomor 
60 tahun 2014 pemerintah Desa akan diberikan dana untuk dikelola guna membiayai penyelenggaraan, pelaksanaan pembangunan, pembinaan masyarakat dan pemberdayaan masyarakat. Bila mengacu pada PP Nomor 60 tahun 2014 sudah cukup jelas bahwa alokasi dana yang diberikan ke masing-masing Desa sangat besar yakni dihitung berdasarkan jumlah penduduk desa, jumlah wilayah Desa, angka kemiskinan Desa dan tingkat kesulitan geografis. Dana ini cukup besar untuk digunakan oleh pemerintah Desa guna memperbaiki kesejahteraan warga di Desa masing-masing. Sebagai informasi, data yang diperoleh dari (IACF2010) menyebutkan bahwa kabupaten Belitung Timur memperoleh alokasi dana desa (ADD) tahun 2014 sebesar Rp1 Miliar. Namun sama halnya dengan pemerintah lainnya, secara umum pemerintah Desa masih belum bisa mengalokasikan dana Desa tersebut sehingga sering terjadi permasalahan dalam hal akuntabilitas dan transparansi dalam pengelolaan ADD. Di Kabupaten Sigi misalnya, berdasarkan pengamatan peneliti pengetahuan masyarakat terutama pemerintah Desa di daerah tersebut masih minim dalam mengelola dana keuangan desa. Kompetensi yang dimiliki oleh pemerintah Desa terkait pengelolaan dana Desamasih belum mampu mengelola dana tersebut. Selain di Kabupaten Sigi, di Kabupaten lain misalnya di Kabupaten Donggala pengetahuan akan mengelola dana desa bahkan membuat laporan keuangan masih sangat minim sehingga yang dikhawatirkan adanya sebuah asymmetry information yang terjadi atas laporan keuangan di publikasikan kepada publik. Penelitian sebelumnya telah banyak meneliti mengenai faktor-faktor yang bisa memengaruhi akuntabilitas dan transparansi suat organisasi. Seperti penelitian yang dilakukan oleh (Laswadet al.,2005; Grimmelikhuijsen2013; Fung et al., 2007; Cheng et al., 2002; dan Kalbers dan Fogarty1995).

Berbeda dengan penelitian yang dilakukan oleh Jermias dan Setiawan (2008) melakukan penelitian di tiga kota besar di Indonesia untuk mengetahui pengaruh partisipasi anggaran terhadap kinerja dengan dimoderasi oleh sistem pengendalian dan hierarchical level suatu unit pemerintahan. Hasil penelitian ini menunjukkan bahwa partisipasi anggaran berpengaruh positif terhadap kinerja pemerintahan.Lebih lanjut, penelitian ini juga memberikan bukti bahwa variabel moderasi yaitu sistem pengendalian dan hierarchical level memperkuat hubungan antar variabel partisipasi anggaran dan kinerja pemerintahan.Namun penelitian ini hanya melihat aspek desentralisasi tanpa melihat kompetensi yang dimiliki serta sistem yang seharusnya digunakan untuk meningkatkan akuntabilitas pemerintah publik.

Penelitian ini menggunakan accountability framework yang dikembangkan olehlyoha dan Oyerinde(2009) untuk menginvestigasi secara komprehensif faktor-faktor yang dapat menentukan tingkat akuntabilitas Alokasi Dana Desa (ADD). Lebih lanjut, lyoha dan Oyerinde(2009) mengemukakan bahwa accountability framework yang dikembangkan merupakan tingkatan/level akuntansi agar akuntabilitas publik bisa berjalan dengan baik yang dimulai dari tahapan accounting infrastructure yaitu mengungkap tentang sejauh mana akuntan yang professional mampu mengelola dana keuangan sehingga harapannya informasi yang 
dihasilkan menjadi tepat waktu, dapat diandalkan dan memadai. Lebih lanjut, tahapan selanjutnya adalah accounting practice dan accounting culture.Kedua poin ini menjadi fokus dalam accountability framework (lyoha dan Oyerinde 2009) karena baik accounting practice dan accounting culture mengungkap bahwa dalam proses akuntabilitas pemerintahan dipengaruhi oleh standar akuntansi internasional yang harus diterapkan ke negara Indonesia, lebih khususnya lagi adalah pemerintah daerah. Selain itu, tingkatan akuntabilitas publik dipengaruhi oleh sistem informasi yang saling terintegrasi yang sebaiknya informasi tersebut tepat waktu, memadai, dapat diandalkan serta relevan dengan kebutuhan stakeholdersdalam hal ini adalah rakyat (lyoha dan Oyerinde 2009).

Dalam accountability framework, faktor individu dan sistem yang diterapkan dalam sebuah pemerintahan menjadi fokus penting dalam meningkatkan akuntabilitas. Kompetensi yang dimiliki oleh pengelola dana desa menjadi syarat utama agar akuntabilitas desa bisa berjalan denga maksimal. Namun tidak hanya itu sistem pengendalian yang digunakan juga sangat mendukung keberhasilan akuntabilitas desa.Dengan mengacupada penelitian dilakukan oleh (Nofianto dan Suseno2014); (Jermias dan Setiawan 2008) serta melihat fenomena yang terjadi di lapangan maka peneliti merumuskan faktor-faktor kondisional yang terdiri atas kompetensi aparatur, dan sistem pengendalian.Kompetensi aparatur mejadi suatu faktor yang penting untuk dibahas mengingat kompetensi merupakan faktor internal dan menjadi suatu yang penting. Kompetensi aparatur di pemerintah desa tergolong masih sangat lemah ketika harus mengelola alokasi dana desa (ADD) yang terbilang cukup besar. Kondisi serupa dipertegas oleh (Leunget al.,2009) yang menjelaskan mengenai pentingnya peran auditor internal dalam mendukung corporate governance sebuah entitas.Namun agar peran auditor internal berhasil guna mendukung corporate governance maka diperlukan kompetensi yang cukup dalam menjamin keberhasilan manajemen dan integritas dalam suatu entitas.

Faktor kedua dalam mendukung akuntabilitas adalah sistem pengendalian internal. Sistem pengendalian internal yang merupakan bagian dari proses untuk mewujudkan akuntabilitas pemerintahan publik, dinilai masih belum mampu untuk dapat memberikan akuntabilitas publik dengan adanya opini dari BPK terhadap laporan keuangan pemerintah yang dihasilkan oleh pemerintah. Berdasarkan sumber yang diperoleh di BPK terdapat hasil pemeriksaan LKPD Kabupaten Donggala masih terdapat kelemahan-kelemahan dalam implementasi sistem pengendalian intern dan ketidakpatuhan pada peraturan perundangundangan, Hal ini mencerminkan bahwa tingkat pengendalian intern pemerintahan masih kurang efektif.

Faktor kompetensi, dan sistem pengendalian yang telah diuraikan sebelumnya diduga dapat memengaruhi tingkat akuntabilitas alokasi dana desa (ADD) Pemerintah Desa. Semakin tinggi kompetensi yang dimiliki oleh seseorang dalam hal aparatur pemerintah, sistem pengendalian dari pihak internal yaitu inspektorat yang semakin tinggi maka dapat 
meningkatkan akuntabilitas Pemerintah desa terhadap publik. Level ini dapat dikategorikan sebagai bagian accounting infrastructure, accounting culture, dan accounting practice berdasarkan accountability framework yang dikembangkan oleh (lyoha dan Oyerinde 2009).

Akuntabilitas merupakan salah satu konsep yang penting dimiliki oleh perusahaan sebagai bentuk pertanggungjawaban kepada stakeholder.Tidak hanya entitas bisnis, namun pada pemerintahan publik dalam hal ini Pemerintah Desa bentuk pertanggungjawaban kepada stakeholder/rakyat merupakan sebuah tuntutan yang harus dipenuhi oleh pemerintah selaku pengelola.Hal ini penting mengingat bila sebuah pemerintah melakukan akuntabilitas dengan melaporkan segala aktivitas yang terjadi di lingkungan pemerintah maka hal ini dapat meningkatkan reputasi pemerintah tersebut sehingga ke depannya pemerintah mendapat banyak dukungan dari stakeholders dalam menjalankan pemerintahan. Namun yang terjadi di lapangan khususnya Pemerintahan Desa akuntabilitas tidak berjalan seperti yang diharapkan.Adanya Alokasi Dana Desa (ADD) yang bertujuan untuk mensejahterakan rakyat tidak berjalan sesuai dengan harapan.Fenomena yang ditemukan oleh peneliti, perkembangan yang berhasil dilakukan tidak sesuai dengan ADD yang telah dikeluarkan oleh Pemerintah Pusat.Infrastructure Desa, peningkatkan kompetensi sumber daya manusia (SDM) belum banyak dilakukan perubahan.Sehingga berdasarkan temuan peneliti di lapangan dan ketidakkonsistenan serta perdebatan hasil penelitian sebelumnya memotivasi peneliti untuk menginvestigasi lebih lanjut dan melakukan pemetaan terkait dengan faktor-faktor yang memengaruhi akuntabilitas dalam pengelolaan ADD dengan menggunakan accountability framework yang dikembangkan oleh lyoha dan Oyerinde (2009). Hal ini penting karena pemahaman terhadap faktor-faktor tersebut merupakan langkah awal untuk menyusun strategi yang tepat dalam mengintegrasikan faktor-faktor tersebut dalam peningkatan akuntabilitas pengelolaan ADD sehingga Pemerintah baik Pusat maupun Desa dapat mengambil kebijakan sekaligus melakukan pelatihan SDM untuk menunjang pengelolaan ADD yang pada akhirnya visi dan misi Pemerintah Desa dapat tercapai.

Berdasarkan pada latar belakang penelitian tersebut di atas, maka penulis merumuskan masalah dalam penelitian ini adalah:1) Apakah faktor kompetensi diproksikan oleh pengetahuan, kualitas pemimpin, etika dan keterampilan, pengalaman dari aparatur Pemerintah Desa memengaruhi tingkat akuntabilitas dalam mengelola dana desa?; 2) Apakah faktor sistem pengendalian internal pemerintah yang diproksikan oleh dedikasi, kewajiban sosial, tuntutan otonomi, self-regulation, dan community affiliation memengaruhi tingkat akuntabilitas pengelolaan dana desa aparatur Pemerintah Desa?; 3) Sejauh manakah level penerapan faktor-faktor tersebut dengan menggunakan accountability framework (accountability infrastructure, accountability practice dan accountability culture)?; 4) Apa saja kendala yang dihadapi oleh aparatur pemerintah untuk meningkatkan akuntabilitas pengelolaan alokasi dana desa (ADD)? 
Tujuan penelitian ini adalah: 1) Untuk mengetahui dan menganalisis pengaruh kompetensi terhadap akuntabilitas pemerintah desa dalam mengelola dana desa; 2) Untuk mengetahui dan menganalisis pengaruh sistem pengendalian internal pemerintah terhadap akuntabilitas pemerintah desa dalam mengelola dana desa; 3) untuk mengetahui Sejauh mana level penerapan faktor kompetensi dan sistem pengendalian internal tersebut dengan menggunakan accountability framework (accountability infrastructure, accountability practice dan accountability culture); 4) Untuk mengetahui apa saja kendala yang dihadapi oleh aparatur pemerintah untuk meningkatkan akuntabilitas pengelolaan alokasi dana desa (ADD).

\section{Tinjauan Pustaka}

\subsection{Kompetensi}

Kompetensi pada umumnya diartikan sebagai kecakapan, keterampilan, kemampuan. Kata dasarnya sendiri, yaitu kompeten, yang berarti cakap, mampu, atau terampil. Pada konteks manajemen Sumber Daya Manusia, istilah kompetensi mengacu kepada atribut / karakteristik seseorang yang membuatnya berhasil dalam pekerjaannya.

McClelland dalam Sagala dan Rivai (2009) mendefinisikan kompetensi (competency) sebagai karakteristik yang mendasar yang dimiliki seseorang yang berpengaruh langsung terhadap, atau dapat memprediksikan, kinerja yang sangat baik. Dengan kata lain, kompetensi adalah apa yang para outstanding performerslakukan lebih sering pada lebih banyak situasi dengan hasil yang lebih baik, daripada apa yang dilakukan para averageperformers.

Airswort, Smith dan Millership (2007:73) mengatakan bahwa kompetensi merupakan kombinasi pengetahuan dan keterampilan yang relevan dengan pekerjaaan. Kompetensi adalah kapasitas untuk menangaani suatu pekerjaan atau tugas berdasarkan suatu standar yang telah ditetapkan.

Menurut Rudana (2005:6), kompetensi merujuk kepada pengetahuan (knowledge), keahlian (skills) dan kemampuan (abilities), yang dapat didemonstrasikan yang dilakukan dengan standar tertentu. Kompetensi dapat diobservasi ,merupakan tindakan perilaku yang memerlukan kombinasi dari ketiga hal ini. Kompetensi ini ditunjukkan dalam konteks pekerjaan dan dipengaruhi oleh budaya organisasi dan lingkungan kerja. Dengan kata lain, kompetensi meliputi kombinasi dari pengetahuan,keahlian dan kemampuan yang diperlukan untuk melakukan pekerjaan atau fungsi didalam setting pekerjaan.

Pengertian kompentensi menurut Robbins (2007:38) bahwa kompetensi adalah kemampuan (ability) atau kapasitas seseorang untuk mengerjakan berbagai tugas dalam suatu pekerjaan dimana kemampuan ini ditentukan oleh 2 (dua) faktor yaitu kemampuan intelektual dan kemampuan fisik. 


\subsection{Sistem Pengendalian Internal}

Sistem Pengendalian Intern (SPI) menurut Peraturan Pemerintah Nomor 60 Tahun 2008 adalah "Proses yang integral pada tindakan dan kegiatan yang dilakukan secara terus menerus oleh pimpinan dan seluruh pegawai untuk memberikan keyakinan memadai atas tercapainya tujuan organisasi melalui kegiatan yang efektif dan efisien, keandalan pelaporan keuangan , pengamanan aset negara, dan ketaatan terhadap Peraturan Perundang - undangan“. Sedangkan Sistem Pengendalian Intern Pemerintah (SPIP) adalah Sistem Pengendalian intern yang diselenggarakan secara menyeluruh dilingkungan pemerintah pusat dan pemerintah daerah.

Inspektorat daerah di Indonesia diatur dalam Peraturan Pemerintah Nomor 60 tahun 2008 tentang SPIP pada bagian kedua mengenai Pengawasan Intern atas Penyelenggaraan Tugas dan Fungsi Instansi Pemerintah. Inspektorat daerah merupakan pengawas internal (internal auditor) dalam pemerintah daerah. Sebagai pengawas internal, keberadaan inspektorat daerah dinilai sangat penting dilihat juga dari fungsi dasarnya yaitu melakukan pengawasan pada seluruh kegiatan yang berkaitan dengan tugas dan fungsi perangkat daerah sesuai dengan anggaran pendapatan dan belanja daerah (APBD). Pengawasan pemerintah meningkatkan akuntabilitas keuangan melalui evaluasi dan perbaikan pengendalian internal, manajemen risiko dan proses tata kelola pemerintahan (Aikins 2011).

Tujuan Sistem Pengendalian Intern Pemerintah Menurut PP No. 60 Tahun 2008 adalah untuk memberi keyakinan yang memadai tentang ; kegiatan yang efektif dan efisien, laporan keuangan yang dapat diandalkan, pengamanan aset negara dan ketaatan terhadap Peraturan Perundang - Undangan. Adapun unsur-unsur Sistem Pengendalian Intern Pemerintah, yaitu Lingkungan Pengendalian, Penilaian Risiko, kegiatan pengendalian, informasi dan komunikasi dan Pemantauan Pengendalian Intern.

\subsection{Alokasi Dana Desa}

Alokasi dana desa adalah anggaran keuangan yang diberikan pemerintah kepada Desa yang mana sumbernya berasal dari Bagi Hasil Pajak Daerah serta dari Dana Perimbangan Keuangan Pusat dan Daerah yang diterima oleh Kabupaten. Sesuai dengan Peraturan Menteri Dalam Negeri No. 37 Tahun 2007 Tentang Pedoman Pengelolaan Keuangan Desa di dalam Pasal 18 menyatakan bahwa Alokasi Dana Desa berasal dari APBD Kabupaten/Kota yang bersumber dari Dana Perimbangan Keuangan Pusat dan Daerah yang diterima oleh Pemerintahh Kabupaten/Kota untuk desa paling sedikit 10\% (sepuluh persen).Pengelolaan Alokasi Dana Desa harus memenuhi beberapa prinsip pengelolaan:

a. Setiap kegiatan yang pendanaannya diambil dari Alokasi Dana Desa harus melalui 
perencanaan, pelaksanaan dan evaluasi secara terbuka dengan prinsip : dari, oleh dan untuk masyarakat;

b. Seluruh kegiatan dan Penggunaan Alokasi Dana Desa harus dapat dipertanggungjawabkan secara administrasi, teknis dan hukum;

c. Alokasi Dana Desa harus digunakan dengan prinsip hemat, terarah dan terkendali;

d. Jenis kegiatan yang akan didanai melalui Alokasi Dana Desa diharapkan mampu untuk meningkatkan sarana pelayanan masyarakat, berupa peenuhan kebutuhan dasar, penguatan kelembagaan desa dan kegiatan lainnya yang dibutuhkan masyarakat desa dengan pengambilan keputusan melalui jalan musyawarah;

e. Alokasi Dana Desa harus di catat di dalam Anggaran Pendapatan dan Belanja Desa melalui proses penganggaran yang sesuai dengan mekanisme yang berlaku.

\subsection{Akuntabilitas dan Accountability Framework}

Konsep mengenai akuntabilitas merupakan suatu konsep yang harus dilaksanakan baik terhadap entitas swasta maupun publik. Boven (2006) menambahkan bahwa akuntabilitas merupakan bentuk interaksi antara pihak pengelola dan masyarakat//forum. Pengelola memiliki kewajiban untuk memberikan suatu penjelasan kepada masyarakat/forum terkait keadaan yang sebenarnya terjadi di organisasi.Hal ini penting mengingat publik, selaku prinsipal perlu mengetahui segala sesuatu yang terjadi di masyarakat/publik. Lebih lanjut, lyoha dan Oyerinde (2010) menambahkan bahwa bahwa tingkat akuntabilitas akan sangat memengaruhi kepuasan/satisfaction dari publik, sehingga peran dari agent (pihak pengelola) menjadi penting agar tingkat akuntabilitas publik menjadi berhasil.

Menurut Lembaga Administrasi Negara dan Badan Pengawasan Keuangan dan Pembangunan RI (2000:12), akuntabilitas adalah kewajiban untuk memberikan pertanggungjawaban atau menjawab dan menerangkan kinerja dan tindakan seseorang/pimpinan suatu unit organisasi kepada pihak yang memiliki hak atau yang berwenang meminta pertanggungjawaban.Akuntabilitas adalah hal yang penting untuk menjamin nilai-nilai seperti efisiensi, efektifitas, reliabilitas dan prediktibilitas. Suatu akuntabilitas tidak abstrak tapi kongkrit dan harus ditentukan oleh hukum melalui seperangkat prosedur yang sangat spesifik mengenai masalah apa saja yang harus dipertanggungjawabkan.

Sulistiyani (2004) menyatakan bahwa transparansi dan akuntabilitas adalah dua kata kunci dalam penyelenggaraan pemerintahan maupun penyelenggaraan perusahaan yang baik, dinyatakan juga bahwa dalam akuntabilitas terkandung kewajiban untuk menyajikan dan melaporkan segala kegiatan terutama dalam bidang administrasi keuangan kepada pihak yang lebih tinggi.Akuntabilitas dapat dilaksanakan dengan memberikan akses kepada semua pihak yang berkepentingan, bertanya atau menggugat pertanggungjawaban para pengambil 
keputusan dan pelaksana baik ditingkat program, daerah dan masyarakat. Dalam hal ini maka semua kegiatan yang berkaitan dengan pengelolaan Alokasi Dana Desa harus dapat diakses oleh semua unsur yang berkepentingan terutama masyarakat di wilayahnya.

Penelitian ini menggunakan accounting framework yang dikembangkan oleh Isyoha dan Oyerinde (2010) untuk menginvestigasi faktor-faktor yang memengaruhi akuntabilitas publik.Pada model ini membahas mengenai beberapa jalur yang dapat memengaruhi akuntabilitas.Model ini terbagi atas beberapa tahapan akuntabilitas dalam mengimplementasikan sebuah anggaran yang telah ditetapkan oleh pemerintah pusat. Berikut merupakan tahap-tahap accountability framework:

1. Accounting Infrastructure: Ini merupakan tahapan dimana struktur untuk mendukung sistem akuntansi di suatu organisasi harus kuat. Ketika struktur yang dimiliki lemah maka akan membuat tingkat akuntabilitas semakin lemah. Sehingga nantinya slemah/kuat tahapan ini akan sangat memengaruhi tahapan lainnya.

2. Accounting Practice: Ini merupakan tahapan dimana sistem akuntansi harus bekerja seperti yang seharusnya. Pada tahapan ini sangat dipengaruhi oleh tahapan sebelumnya yaitu accounting infrastructure.

3. Accounting Culture: Ini merupakan tahapan yang berkaitan dengan budaya yang terjadi di suatu organisasi. Budaya ini sangat memengaruhi perilaku individu maupun kelompok suatu organisasi bekerja. Pada tahapan Pada tahapan ini juga sangat dipengaruhi oleh tahapan sebelumnya yaitu accounting infrastructure. Terjadi sebuah hubungan antara accounting Practice dan accounting culture. Hubungan ini terjadi dikarenakan praktik akuntansi tidak hanya dapat memengaruhi hasil namun juga dapat memengaruhi perilaku suatu organisasi/budaya. Dan sebaliknya budaya akuntansi dalam suatu organisasi dapat memengaruhi praktik akuntansi.

4. Budget Implementation/Performance: Ini merupakan tahapan yang berkaitan mengenai implementasi dari anggaran yang telah ditetapkan oleh pemerintah. Dengan mengacu pada UU Nomor 24 tahun 2014, pemerintah daerah diberikan kewenangan untuk membuat anggaran dan melaksanakannya. Sehingga peran accountability infrastructure, serta accounting practice dan accounting culture akan sangat memengaruhi kinerja Pemerintah Daerah.

5. Management of Public Expenditure: Ini merupakan tahapan kebijakan yang dihasilkan untuk kepentingan publik. Pada tahapan ini merupakan tahapan akhir yang akan mengacu dari implementasi akuntabilitas yang telah diterapkan sebelumnya. 


\subsection{Penelitian Terdahulu}

Komanget al. (2014) Pengaruh Sistem Pegendalian Intern Pemerintah dan Pengawasan Keuangan Daerah Terhadap Nilai Informasi Laporan Keuangan Pemerintah Pada Satuan Kerja Perangkat Daerah (SKPD). Hasil penelitian menunjukkan bahwa ada pengaruh positif dan signifikan dari sistem pengendalian intern pemerintah dan pengawasan keuangan daerah terhadap nilai informasi keuangan, sistem pengendalian intern pemerintah terhadap pengawasan keuangan daerah, sistem pengendalian intern pemerintah terhadap nilai informasi keuangan dan pengawasan keuangan daerah terhadap nilai informasi laporan keuangan pada SKPD di Kabupaten Buleleng.

Zirman et al. (2010) melakukan penelitian dengan judul Pengaruh Kompetensi Aparatur Pemerintah Daerah, Penerapan Akuntabilitas Keuangan, Motivasi Kerja dan Ketaatan pada Peraturan Perundang - Undangan terhadap Akuntabilitas Kinerja Instansi Pemerintah. Dalam penelitian ini yang menjadi variabel independen (variabel $\mathrm{x}$ ) adalah kompetensi aparatur pemerintah daerah, penerapan akuntabilitas keuangan, motivasi kerja dan ketaatan pada Peraturan Perundang - undangan dan sebagai variabel dependen $(\mathrm{Y})$ adalah Akuntabilitas Kinerja Instansi Pemerintah. Hasil penelitian menunjukkan bahwa Kompetensi Aparatur Pemerintah Daerah berpengaruh positif dan penerapan Akuntabilitas Keuangan menghasilkan pengaruh yang negatif terhadap Akuntabilitas Kinerja Instansi Pemerintah. Ketaatan pada Peraturan Perundangan juga memiliki pengaruh positif dan signifikan terhadap Akuntabilitas Kinerja Instansi Pemerintah Sedangkan nilai R square sebesar 0,142 yang berarti $14,2 \%$ variabel - variabel independen dalam penelitian ini mampu mempengaruhi variabel dependen.

Astuti (2016) melakukan penelitian dengan Judul Pengaruh Sistem Pengendalian Intern terhadap Kualitas Laporan Keuangan Implikasinya Terhadap Akuntabilitas Kinerja Instansi Pemerintah (Survei Pada Dinas Kota Badung. Hasil penelitian menunjukkan terdapat hubungan antara pengendalian akuntansi terhadap akuntabilitas kinerja sebesar 0,625 yang bernilai positif. Terdapat pengaruh antara sistem pengendalian intern terhadap kualitas laporan keuangan adalah sebesar $42,50 \%$ artinya sistem pengendalian intern memberikan pengaruh terhadap kualitas laporan keuangan sebesar $42,50 \%$ pada instansi pemerintah diseluruh dinas yang ada di Kota Bandung. Untuk variabel pengendalian akuntansi terhadap akuntabilitas kinerja sebesar 0,707 yang bernilai postif sedangkan pengaruh kualitas laporan keuangan terhadap akuntabilitas kinerja instansi pemerintah daerah sebesar 50,00\% pada instansi pemerintah diseluruh Dinas yang ada di Kota Bandung.

Perbedaan penelitian ini dengan ketiga penelitian terdahulu adalah penelitian ini bertujuan untuk mengetahui dan menganalisis pengaruh kompetensi dan sistem pengendalian internal pemerintah terhadap akuntabilitas pemerintah desa dalam mengelola dana desa. Dan penelitian ini juga menggunakan accountability framework(accountability infrastructure, 
accountability practice dan accountability culture)untuk mengetahui Sejauh mana level penerapan faktor kompetensi dan sistem pengendalian internal tersebut dan Untuk mengetahui apa saja kendala yang dihadapi oleh aparatur pemerintah untuk meningkatkan akuntabilitas pengelolaan alokasi dana desa (ADD).

\section{Metodologi Penelitian}

Penelitian ini dikategorikan sebagai explanatory research yang menjelaskan hubungan kausal antar variabel-variabel melalui pengujian hipotesis (Cooper \& Schindler dalam Hartono (2010:12).Penelitian ini memfokuskan pada pengungkapan dan penjelasan secara ilmiah mengenai ada tidaknya pengaruh variabel independen terhadap variabel dependen. Pada penelitian ini juga akan melakukan pemetaan serta menginvestigasi faktor-faktor yang menentukan akuntabilitas dan transparansi oleh Pemerintah Desa. Penelitian akan difokuskan untuk menguji secara empiris sekaligus memetakan faktor-faktor yang memengaruhi individu yang bekerja dalam Pemerintah Desa dalam mengelola Alokasi Dana Desa (ADD).

Penelitian akan dilakukan dalam beberapa tahap. Tahap pertama, peneliti melakukan observasi di lapangan dan studi literatur terkait permasalahan/fenomena yang akan diteliti. Tahap kedua, peneliti merumuskan masalah penelitian. Tahap ketiga, pengumpulan data untuk menjawab permasalahan penelitian. Tahap keempat, peneliti akan melakukan analisis dan olah data terhadap data yang telah terkumpul. Tahap terakhir, interpretasi data dan pengambilan keputusan oleh peneliti.

Populasi penelitian ini adalah aparatur pemerintah Desa Kabupaten Sigi yang berjumlah sekitar 155 orang yang mewakili masing - masing desa di Kabupaten Sigi. Sampling Method menggunakan random sampling. Penelitian ini menggunakan sebagian dari populasi sebagai sampel. Untuk menentukan besarnya sampel digunakan rumus Slovin (Riduwan 2006) sebagai berikut:

$$
\mathrm{n}=\frac{\mathrm{N}}{\mathrm{N} \cdot \mathrm{d}^{2}+1}
$$

Di mana: $\mathrm{n}=$ jumlah sampel

$\mathrm{N}=$ jumlah populasi

$\mathrm{d}^{2}=$ Presisi yang ditetapkan

Berdasarkan perhitungan menggunakan rumus diatas, dihasilkan proporsi sampel sebagai berikut: $\mathrm{n}=155 /\left(155 \times 0,1^{2}+1\right)$, sehingga $\mathrm{n} 61$ sampel. Maka diperoleh sampel sejumlah 61 Desa, dimana masing - masing Desa akan diwakilkan oleh seorang aparatur desa. Sehingga jumlah kuesioner yang akan disebar sejumlah 61 Aparatur Pemerintah Desa.

Data yang digunakan dalam penelitian ini adalah data primer yang langsung diperoleh dari responden. Teknik pengumpulan data menggunakan kuesioner, observasi dan interview 
terhadap responden. Untuk kompetensi aparatur maka dapat diukur dengan tiga dimensi yaitupengetahuan, keterampilan dan sikap. Kompetensi aparatur dalam penelitian ini di ukur dengan didasarkan pada PP No. 101 tahun 2000. Pada variabel sistem pengendalian maka dalam penelitian ini mengadopsi indikator yang digunakan oleh Jermias dan Setiawan (2008). Adapun indikator yang digunakan adalah: 1) Pertimbangan catatan hasil pekerjaan; 2) pengawasan terhadap bawahan yang langsung melaporkan hasil pekerjaannya; 3) Mengamati bawahan dalam melakukan tugasnya; 4) Mempertimbangkan hasil pekerjaan; 5) Fokus pada hasil daripada bagaimana bawahan melakukan kegiatan;6) Pekerjaan harus dilakukan sesuai dengan prosedur dan peraturan yang telah ditetapkan; 7) Prosedur operasi standar dalam melakukan pekerjaan; 8) Lebih mennekankan hasil daripada proses untuk mendapatkan hasil. Tanggapan terhadap delapan item ini diukur dengan menggunakan skla likert 7 Poin. Pada variabel dependen yaitu akuntabilitas maka peneliti mengacu pada PP No. 46 Tahun 2011 tentang Penilaian Prestasi Kerja Pegawai Negeri Sipil. Indikator yang digunakan, yaitu: 1) kuantitas; 2) kualitas; 3) waktu; 4) biaya; 5) orientasi pelayanan; 6) integritas; 7) komitmen; 8) disiplin; 9) kerjasama instrumen tersebut diukur dengan menggunakan skala likert 7 poin.

Pengujian ini akan dilakukan dengan menggunakan multiple regression (regresi berganda). Kuncoro (2009:236) mengatakan bahwa analisis regresi berganda digunakan untuk menganalisis seberapa jauh variasi perubahan variabel independen mampu dijelaskan oleh seluruh variabel independen yang dimasukkan dalam model. Kaidah pengujian signifikansi 0,05 lebih kecil atau sama dengan probabilitas sig 0,05,maka Ha diterima dan Ho ditolak artinya signifikan. Pola hubungan antar variabel dapat dilihat pada gambar berikut :

\section{Gambar 1. Model Penelitian}

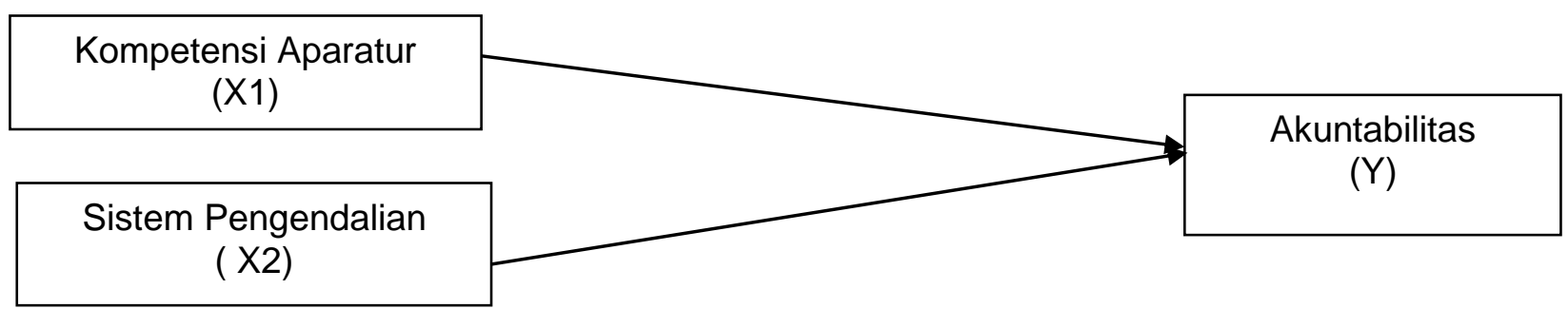




\section{Analisis dan Pembahasan}

\subsection{Pengumpulan Data}

Tabel 1. Tabel Hasil analisis Regresi Berganda

\begin{tabular}{|c|c|c|c|c|c|c|}
\hline \multirow[t]{2}{*}{ Variabel } & \multicolumn{2}{|c|}{$\begin{array}{l}\text { Unstandardized } \\
\text { Coefficients }\end{array}$} & \multirow{2}{*}{$\begin{array}{c}\text { Standardize } \\
d \\
\text { Coefficients } \\
\text { Beta }\end{array}$} & \multirow[t]{2}{*}{$\mathrm{T}$} & \multirow[t]{2}{*}{ Sig. } & \multirow[t]{2}{*}{ Keterangar } \\
\hline & B & Std. Error & & & & \\
\hline \multirow{2}{*}{$\begin{array}{l}\text { (Constant) } \\
\text { Kompetensi }\end{array}$} & 12.514 & 2.953 & & 4.237 & 0.000 & \\
\hline & 0.148 & 0.122 & 0.157 & 1.219 & 0.228 & $\begin{array}{c}\text { Tidak } \\
\text { signifikan }\end{array}$ \\
\hline $\begin{array}{l}\text { S. } \\
\text { Pengendalian }\end{array}$ & 0.340 & 0.136 & 0.321 & 2.500 & 0.015 & Signifikan \\
\hline
\end{tabular}

Sumber: Data diolah sendiri

Hasil dari analisis regresi berganda pada Tabel 1, kemudian dimasukkan ke dalam model persamaan regresi berganda dengan formulasi berikut: $Y=12,514-0,148 X_{1}+0,340 X_{2}+e$

Persamaan tersebut menunjukkan, variabel bebas $\left(X_{1}\right.$, dan $\left.X_{2}\right)$ yang di analisis memberikan pengaruh terhadap akuntabilitas pengelolaan alokasi dana desa (ADD).

a. Nilai konstanta $=12,514$ dapat diartikan bahwa rata-rata kontribusi variabel lain diluar model memberikan dampak positif terhadap akuntabilitas pengelolaan ADD.

b. Koefisien regresi variabel kompetensi $\left(X_{1}\right)$ sebesar 0,148 , ini berarti variabel kompetensi aparatur pemerintah Desa berpengaruh terhadap akuntabilitas dalam pengelolaan Alokasi Dana Desa sehingga jika variabel lain dianggap konstan maka akuntabilitas pengelolaan ADD akan meningkat sebesar 0,148 .

c. Koefisien regresi variabel sistem pengendalian $\left(X_{2}\right)$ sebesar 0,340 , ini berarti variabel sistem pengendalian berpengaruh terhadap akuntabilitas pengelolaan ADD sehingga jika variabel lain konstan maka akuntabilitas akan meningkat sebesar 0,340.

Berdasarkan data tersebut juga dapat diperoleh sebuah simpulan mengenai hasil pengujian hipotesis sebagai berikut:

a. Variabel kompetensi aparatur $\left(X_{1}\right)$ diperoleh nilai signifikansinya lebih besar dari taraf ketidakpercayaan $5 \%$ yaitu $0,228>0,05$. Nilai ini menunjukkan bahwa variabel kompetensi aparatur $\left(X_{1}\right)$ tidak berpengaruh signifikan terhadap akuntabilitas dalam pengelolaan ADD $(Y)$. Berdasarkan hasil tersebut maka hipotesis pertama ditolak.

b. Variabel sistem pengendalian $\left(X_{2}\right)$ menghasilkan nilai signifikansinya lebih kecil dari taraf ketidakpercayaan $5 \%$ yaitu $0,015<0,05$. Nilai ini menunjukkan bahwa variabel sistem pengendalian $\left(\mathrm{X}_{2}\right)$ memberikan pengaruh positif terhadap akuntabilitas dalam pengelolaan ADD (Y). Berdasarkan hasil tersebut maka hipotesis kedua diterima.

Hasil pengujian untuk hipotesis pertama dalam penelitian ini adalah bahwa variabel 
kompetensi aparatur $\left(\mathrm{X}_{1}\right)$ diperoleh nilai signifikansinya lebih besar dari taraf ketidakpercayaan $5 \%$ yaitu $0,228>0,05$. Nilai ini menunjukkan bahwa variabel kompetensi aparatur $\left(X_{1}\right)$ tidak berpengaruh signifikan terhadap akuntabilitas dalam pengelolaan ADD (Y).Sedangkan untuk variabel Sistem Pengendalian $\left(\mathrm{X}_{2}\right)$ menghasilkan nilai signifikansinya lebih kecil dari taraf ketidakpercayaan $5 \%$ yaitu $0,015<0,05$. Nilai ini menunjukkan bahwa variabel sistem pengendalian $\left(\mathrm{X}_{2}\right)$ memberikan pengaruh positif terhadap akuntabilitas dalam pengelolaan ADD $(\mathrm{Y})$.

\subsection{Pengaruh Kompetensi Aparatur terhadap Akuntabilitas Pengelolaan Alokasi Dana Desa}

Hasil penelitian tersebut menunjukkan bahwa kompetensi aparatur dari Pemerintah Desa secara signifikan tidak mempengaruhi akuntabilitas pengelolaan keuangan Alokasi Dana Desa (ADD). Hal ini berbeda dengan hipotesis yang telah diajukan sebelumnya yang menyebutkan bahwa kompetensi mempengaruhi akuntabilitas pengelolaan Alokasi Dana Desa (ADD). Hal ini disebabkan Aparatur Pemerintah Desa yang melaksanakan pengelolaan administrasi keuangan belum sesuai dengan ketentuan - ketentuan berikut, :

1. Kurang efektifnya sistem pembinaan dari pemerintah kecamatan dan pemerintah kabupaten terhadap pengelola Alokasi Dana Desa (ADD) ditingkat desa;

2. Rendahnya kompetensi maupun tingkat pendidikan yang merupakan ujung tombak pelaksanaan Alokasi Dana Desa (ADD). Hal ini didukung dengan hasil kuesioner dimana sebagian responden Aparatur Pemerintah Desa latar belakang pendidikannya di dominasi lulusan (SMA) sehingga rendahnya kompetensi Aparatur Pemerintah Desa akan mempengaruhi akuntabilitas dan transparansi pemerintah Desa.

Kompetensi aparatur merupakan aspek pribadi dari seorang pekerja yang memungkinkan seseorang mencapai kinerja yang baik. Aspek -aspek pribadi ini mencakup sifat, motif, sistem nilai, sikap, pengetahuan dan keterampilan dimana kompetensi akan mengarahkan tingkah laku, sedangkan tingkah laku akan menghasikan kinerja. Kompetensi aparatur menjadi suatu faktor yang penting mengingat kompetensi merupakan faktor internal dan menjadi suatu yang penting. Dimana berdasarkan penelitian kompetensi aparatur pemerintah desa tergolong masih sangat lemah ketika harus mengelola alokasi dana desa (ADD) yang terbilang cukup besar. Hal ini didukung dengan jawaban responden pada kuesioner bahwa rata - rata menjawab ragu - ragu mengenai pengetahuan dan pemahaman dalam penyajian laporan keuangan. 


\subsection{Pengaruh Sistem Pengendalian terhadap Akuntabilitas Pengelolaan Alokasi Dana Desa}

Hasil penelitian tersebut menunjukkan bahwa sistem pengendalian aparatur dari Pemerintah Desa memberikan pengaruh positif terhadap akuntabilitas dalam pengelolaan ADD (Y). Hal ini sejalan dengan hipotesis yang telah diajukan sebelumnya yang menyebutkan bahwa sistem pengendalian mempengaruhi akuntabilitas pengelolaan Alokasi Dana Desa (ADD). Dan sejalan dengan yang dikemukan oleh (Aikins 2011) bahwa pengawasan pemerintah meningkatkan akuntabilitas keuangan melalui evaluasi dan perbaikan pengendalian internal, manajemen risiko daan proses tata kelola pemerintahan.

Penyelenggaraan kegiatan dalam suatu pemerintah mulai dari perencanaan, pelaksanaan pengawasan,sampai dengan pertanggungjawaban harus dilaksanakan secara tertib, terkendali serta efesien dan efektif. Untuk itu dibutuhkan suatu sistem yang dapat memberi keyakinan memadai bahwa penyelenggaraan kegiatan pada suatu instansi pemerintah dapat mencapai tujuannya secara efisien dan efektif, melaporkan pengelolaan keuangan secara andal, mengamankan aset dan mendorong ketaatan terhadap peraturan perundang - undangan. Sistem ini dikenal sebagai Sistem Pengendalian Internal.

Sistem Pengendalian Internal dalam Pemerintahan merupakan faktor yang penting, disebabkan dengan adanya sistem pengendalian dapat mempengaruhi pengambilan keputusan internal pemerintah desa dan dapat berimplikasi pada akuntabilitas dan transparansi pemerintah desa tersebut.

\subsection{Penerapan Accountability Framework}

Penerapan Faktor Kompentensi dan Sistem Pengendalian Internal Pemerintah dengan menggunakan Accountability Framework .Penerapan Accountability Framework terbagi 3 tahap:

a. Accountability Infrastructure, tahapan dimana struktur untuk mendukung sistem akuntansi disuatu organisasi harus kuat. Ketika struktur yang dimiliki lemah maka akan membuat tingkat akuntabilitas semakin lemah. Sehingga nantinya lemah / kuat tahapan ini akan sangat mempengaruhi tahapan lainnya. Penerapan Kompetensi dan Sistem Pengendalian Internal Pemerintah dengan menggunakan Accountability Infrastructure untuk level penerapannya masih lemah di lihat dari faktor kompetensi yang tidak berpengaruh signifikan terhadap akuntabilitas meskipun faktor sistem pengendalian internal pemerintah berpengaruh signifikan terhadap akuntabilitas pengelolaan Alokasi Dana Desa (ADD) tetapi ada faktor lain diluar penelitian ini yang lebih berpengaruh terhadap akuntabilitas sebagai contoh Penerapan Akuntabilitas Keuangan, Motivasi Kerja, Ketaatan pada Peraturan Perundangan dan lain - lain. 
b. Accounting Practice, ini merupakan tahapan dimana sistem akuntansi harus bekerja seperti seharusnya. Pada tahapan ini sangat dipengaruhi oleh tahapan sebelumnya, yaitu Accounting Infrastructure. Karena Accounting Infrastructure-nya lemah maka level penerapan faktor kompetensi dan faktor sistem pengendalian internal juga lemah. Hal ini dititikberatkan pada lemahnya kompetensi yang dimiliki Aparatur Pemerintah Desa dalam mengelola Alokasi Dana Desa (ADD).

c. Accounting Culture, ini merupakan tahapan yang berkaitan dengan budaya yang terjadi disuatu organisasi. Budaya ini sangat mempengaruhi perilaku individu maupun kelompok suatu organisasi bekerja. Pada tahapan ini sangat dipengaruhi oleh tahapan sebelumnya yaitu accounting infastructure dan accounting practice. Penerapan faktor kompetensi dan faktor sistem pengendalian internal dengan menggunakan Accounting Culture masih berada dilevel yang lemah. Hal ini dikarenakan perilaku kerja Pemerintah Desa yang mengelola ADD belum sesuai dengan yang diharapkan.

\subsection{Kendala yang dihadapi Aparatur Pemerintah Desa Dalam Pengelolaan Dana Alokasi $\operatorname{Desa}(A D D)$}

Dalam Pengelolaan Dana Alokasi desa ada beberapa kendala yang di hadapi oleh Aparatur Pemerintah desa yaitu lemahnya kompetensi sumber daya manusia aparatur desa dalam hal ini aparatur pemerintah desa rata - rata berpendidikan (SMA), minimnya pengetahuan aparatur desa dalam hal penyajian dan penyusunan laporan keuangan dalam hal ini rata - rata responden menjawab ragu - ragu mengenai mekanisme dan teknik sistem akuntansi pemerintahan. Selain itu Pemahaman responden dalam menggunakan komputer untuk bekerja masih rendah dan kurangnya minat untuk mengikuti pelatihan untuk menambah pengetahuan mengenai pengelolaan Alokasi Dana Desa (ADD) sehingga pemahaman memadai mengenai standar akuntansi pemerintahan khususnya Peraturan Pemerintah No 71 tahun 2010 belum bisa diterapkan dengan baik.

\section{Kesimpulan, Keterbatasan, dan Saran}

\subsection{Kesimpulan}

Setelah penulis melakukan analisa mengenai Kompetensi dan Sistem Pengendalian Internal terhadap Akuntabilitas Pemerintah Desa dalam Mengelola Dana Alokasi Desa (ADD), maka penulis menyimpulkan sebagai berikut: 
1. Kompetensi Aparatur dari Pemerintah Desa secara signifikan tidak memengaruhi Akuntabiitas Pengelolaan Keuangan Alokasi Dana Desa (ADD).

2. Sistem Pengendalian Aparatur dari Pemerintah Desa secara signifikan mempengaruhi Akuntabilitas Pengelolaan Keuangan lokasi Dana Desa (ADD).

3. Penerapan Faktor Kompentensi dan Sistem Pengendalian Internal Pemerintah dengan menggunakan Accountability Framework .Penerapan Accountability Framework terbagi 3 tahap:

i. Accountability Infrastructure,Penerapan Kompetensi dan Sistem Pengendalian Intern Pemerintah dengan menggunakan Accountability Infrastructure untuk level penerapannya masih lemah di lihat dari faktor kompetensi yang tidak berpengaruh signifikan terhadap akuntabilitas meskipun faktor sistem pengendalian internal pemerintah berpengaruh signifikan terhadap akuntabilitas pengelolaan Alokasi Dana Desa (ADD) tetapi ada faktor lain diluar penelitian ini yang lebih berpengaruh terhadap akuntabilitas sebagai contoh Penerapan Akuntabilitas Keuangan, Motivasi Kerja, Ketaatan pada Peraturan Perundangan dan lain - lain.

ii. Accounting Practice, ini merupakan tahapan dimana sistem akuntansi harus bekerja seperti seharusnya. Pada tahapan ini sangat dipengaruhi oleh tahapan sebelumnya yaitu Accounting Infrastructure. Karena Accounting Infrastructure-nya lemah maka level penerapan faktor kompetensi dan faktor sistem pengendalian internal juga lemah. Hal ini dititik beratkan pada lemahnya kompetensi yang dimiliki AparaturPemerintah Desa dalam mengelola Alokasi Dana Desa (ADD).

iii. Accounting Culture, Penerapan faktor kompetensi dan faktor sistem pengendalian internal dengan menggunakan Accounting Culture masih berada dilevel yang lemah. Hal ini dikarenakan perilaku kerja Pemerintah Desa yang mengelola ADD belum sesuai dengan yang diharapkan.

4. Kendala yang dihadapi Aparatur Pemerintah Desa untuk meningkatkan Akuntabilitas Pengelolaan Alokasi Dana Desa adalah minimnya pengetahuan aparatur pemerintah dalam mengelola dana desa, kurangnya pengetahuan aparatur pemerintah desa dalam hal penyusunan laporan keuangan, kurangnya pemahaman mengenai mekanisme, teknik sistem akuntansi serta standar akuntansi pemerintahan.

\subsection{Keterbatasan Penelitian}

1. Faktor - faktor yang memengaruhi Akuntabilitas Pemerintah dalam mengelola Alokasi Dana Desa (ADD) dalam penelitian ini hanya terdiri dari dua variabel, yaitu Kompetensi dan Sistem Pengendalian Internal, sedangkan masih banyak faktor lain yang mempengaruhi Akuntabilitas dalam mengelola Alokasi Dana Desa (ADD); 
2. Adanya keterbatasan penelitian dengan menggunakan kuesioner yaitu terkadang jawaban yang diberikan oleh sampel tidak menunjukkan keadaan sesungguhnya.

5.3. Saran

Dari beberapa penjelasan dan kesimpulan diatas, maka untuk pencapaian sasaran maksimal dalam meningkatkan akuntabilitas pemerintah desa dalam mengelola Alokasi Dana Desa (ADD) , maka harus ada pembenahan dalam beberapa hal sebagai berikut :

1. Aparatur Pemerintah yang mengelola Alokasi Dana Desa sebaiknya memiliki pengetahuan, keterampilan dan pelatihan mengenai penyusunan laporan keuangan yang baik dan benar sehingga akuntabilitas dapat berjalan baik;

2. Aparatur pemerintah yang bertugas mengelola keuangan sebaiknya berlatar belakang akuntansi atau keuangan;

3. Untuk meningkatkan keberhasilan program Alokasi Dana Desa (ADD) oleh aparatur Pemerintah Desa Kabupaten Sigi perlu dilakukan langkah -langkah sebagai berikut:

a. Pelatihan bagi Perangkat Desa selaku Tim Pelaksana Kecamatan tentang Manajemen dan administrasi pengelolaan ;

b. Penyediaan sarana yang memadai bagi Fasilitasi Kecamatan untuk menunjang kegiatan supervisi, pemantauan, evaluasi dan monitoring kegiatan ADD di Desa ;

c. Dilakukan monitoring dan evaluasi serta berkelanjutan untuk memperbaiki kinerja disemua sisi baik fisik, teknis, maupun administrasi (pertanggungjawaban/SPJ) ;

d. Pembinaan pengelolaan ADD merupakan sarana efektif untuk keberhasilan program ADD. Oleh karena itu pemahaman prinsip partisipatif, transpransi, dan akuntabilitas harus dilakukan seefektif kepada aparat pemerintah desa, BPD, Lembaga kemasyarakatan desa, toko masyarakat dan toko agama guna meningkatkan semangat, motivasi, kreativitas masyarakat dalam pembangunan desa ;

e. Perlu dibangun kepercayaan masyarakat terhadap pemerintah dengan jalan melaksanakan prinsip responsif terhadap kebutuhan atau usulan masyarakat dan merealisasikannya dalam bentuk kegiatan pembangunan lain desa.

\section{Daftar Pustaka}

Aksi-Corruption Forum (IACF) tahun 2010.

Aikins, Stephen K. 2011. An Examination of Government Internal Audit's Role in Improving Financial Performance. Journal of Public Finance and Management, 11 (4): 306-337.

Ainswort, Murray., N. Smith., dan A. Millership. 2007. Managing Performance Managing People. Jakarta. PT. Bhuana Imu Populer.

Astuti, Yulia. 2016. Pengaruh Sistem Pengendalian Intern terhadap Kualitas Laporan Keuangan Implikasinya Terhadap Akuntabilitas Kinerja Instansi Pemerintah (Survei Pada Dinas Kota Badung. Elib. unikom. 
Cheng, R.H., H.E. John., C. Susan,. dan K. Fall. 2002. Educating government Financial Managers: University collaboration between business.

Grimmelikhuijsen, S. 2013. A good man but a bad wizard. About the limits and futureTransparency of democratic governments. Information Policy 17: 293-302.

Hartono, Jogiyanto. 2010. Metodologi Penelitian Bisnis: Salah Kaprah dan PengalamanPengalaman.Yogyakarta. BPFE Yogyakarta.

Iyoha, F.O., dan D. Oyerinde. 2009. Accounting infrastructure and accountability in the management ofPublic expenditure in developing countries: A focus on Nigeria. Critical Perspectives on Accounting 21: 361-373.

Jermias, J., dan T. Setiawan. 2008. The moderating effects of hierarchy and control Systems on the relationship between budgetary participate on and performance. The International Journal of Accounting 43: 68-292.

Jorge,S.M., P. MouraeSá,. A.F. Pattaro,. dan R.P. Lourenço. 2011. Local government financial transparency in Portugal and Italy: A comparative exploratory study on its determinants. Paper presented at 13 Biennial CIGAR Conference, 9-10 June, Ghent, Belgium.

Kalbers, L. P., dan T. J. Fogarty. 1995. Professionalism and Its Consequences: A Study of Internal Auditors. A Journal of Practice and Theory. Spring 14 (1): 64-85.

Kurtz, M. J., dan A. Schrank. 2007. Growth and Governance: Models, Measures, and Mechanisms, The Journal of Politics 69 (2), May 2007, pp. 538-554.

Laswadv, F., R. Fisher., dan P. Oyelere. 2005. Determinants of voluntary Internet financialReporting by local government authorities.Journal of Accounting and Public Policy24: 101-121.

Lembaga Administrasi Negara dan Badan Pengawasan Keuangan dan Pembangunan RI. 2000. Akuntabilitas dan Good Governance, Modul 1-5, Modul Sosialisasi Sistem Akuntabilitas Kinerja Instansi Pemerintah (AKIP), LAN BPKP RI, Jakarta.

Leung, P. 2009. The Role of Internal Audit in Corporate Governance and Management. The Institute of Internal Auditors Inc. Research PP No. 101 tahun 2000 tentang Pendidikan dan Pelatihan Jabatan Pegawai Negeri Sipil.

Narsa, Niluh Putu Dian Rosalina Handayani, and Isnalita Isnalita. "SAK ETAP SEBAGAI SOLUSI OVERLOAD STANDAR AKUNTANSI BAGI UMKM." EKUITAS (Jurnal Ekonomi dan Keuangan) 1, no. 1 (2017): 44-65.

Peraturan Pemerintah Republik Indonesia Nomor 71 tahun 2010 tentang Standar Akuntansi Pemerintahan.

Peraturan Menteri Dalam Negeri No. 37 Tahun 2007 Tentang Pedoman Pengelolaan Keuangan Desa.

Peraturan Pemerintah No. 60 Tahun 2008 tentang Sistem Pengendalian Intern Pemerintah.

Peraturan Pemerintah Republik Indonesia Nomor 60 tahun 2014.

Rudana, N. 2005. Pengaruh Komptensi Aparatur PEMDA dan Komunikasi Interpersonal terhadap Kualitas Pelayanan Publik di Kantor Kabupaten Gianyar. Jurnal Ekonomi. Universitas Diponegoro.

Robbins, S. P. 2007. Perilaku Organisasi, Konsep Kontroversi, Aplikasi. Jakarta:PT. Indeks . Gramedia. Edisi Kesepuluh.

Sagala, R. 2009. Manajemen Sumber Daya Manusia untuk Perusahaan. Rajawali Pers.

Sartika D.K., W. Cipta., dan I W. Bagia. 2014. Pengaruh Sistem Pengendalian Intern Pemerintah dan Pengawasan Keuangan Daerah Terhadap Nilai Informasi Laporan 
Keuangan Pemerintah Pada Satuan Kerja Perangkat Daerah (SKPD). E- Jounal Bisma Universitas Pendidikan Ganesha. Jurusan Manajemen, 2.

Scott, J.K. 2006. "E" the people: Do US municipal government websites support public involvement? Public Administration Review 66 (3): 341-353.

Sulistiyani, A. T. 2004. Kemitraan dan Model-Model Pemberdayaan, Gava Media, Yogyakarta.

Uddin, S., dan T. Hopper. 2001.A Bangladesh soap opera: Privatization, accounting and regimes of controlin a less developed country. Accounting Organizations and Society26: 643-672.

Zirman, Edvan, dan Rozi. 2010. Pengaruh Kompetensi Aparatur Pemerintah Daerah, Penerapan Akuntabilitas Keuangan, Motivasi Kerja dan Ketaatan Pada Peraturan Perundangan terhadap Akuntabilitas Kinerja Instansi Pemerintah. Jurnal Ekonomi 18. 